\title{
Projecting the trees but ignoring the Forest: brief CRITIQUe of Alfredo Pereira Jr.'s TARGET PAPER ${ }^{1}$
}

\author{
Gregory Michael Nixon ${ }^{2}$
}

\begin{abstract}
Pereira's "The projective theory of consciousness" is an experimental statement, drawing on many diverse sources, exploring how consciousness might be produced by a projective mechanism that results both in private selves and an experienced world. Unfortunately, pulling together so many unrelated sources and methods means none gets full attention. Furthermore, it seems to me that the uncomfortable breadth of this paper unnecessarily complicates his project; in fact it may hide what it seeks to reveal. If this conglomeration of diverse sources and methods were compared to trees, the reader may feel like the explorer who cannot see the forest for the trees. Then again, it may be the author who is so preoccupied with foreground figures that the everpresent background is ultimately obscured.
\end{abstract}

KeYwords: Intersubjectivity. Neutral monism. Projection. Hard problem. Cultural construction.

\section{INTRODUCTION}

Alfredo Pereira Jr. is a prolific author who publishes in both Portuguese and English. He has credentials as both a philosopher and a scientist. The span of his interests is wide indeed, covering areas as diverse as brain studies, cognitive science, systems theory, public health care, philosophy of science, and physiological psychology, but with a more recent emphasis on philosophy of mind, especially consciousness studies. I mention this, for these all seem to be present to one degree or another in his target essay for this journal issue, "The projective theory of consciousness: from neuroscience to philosophical psychology" (and I notice that metaphysics is not mentioned in this title). It is

\footnotetext{
${ }^{1}$ I dedicate this critique to Alfredo Pereira Jr. for his untiring research efforts, unique mind, and multidisciplinary scholarship, not to mention his patience with criticism.

2 Professor, University of Northern British Columbia, Prince George - Canada. E-mail: doknyx@ telus.net
}

http://dx.doi.org/10.1590/0101-3173.2018.v41esp.14.p269

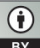


an experimental statement, drawing on many diverse sources, exploring how consciousness might be produced by a projective mechanism. Unfortunately, pulling together so many unrelated sources and methods means none gets full attention. Furthermore, it seems to me that the uncomfortable breadth of this paper unnecessarily complicates his project; in fact it may hide what it seeks to reveal. If this conglomeration of diverse sources were compared to trees, the reader may feel like the explorer who cannot perceive the forest for all the trees in the way. Then again, it may be the author who is so preoccupied with the foreground figures that the everpresent background is ultimately obscured.

This has all the makings of a worthy project - a somewhat fresh approach to the so-called "problem of consciousness" and a skillful and erudite researcher. However, this effort did not work for me. The attempt to be so multidisciplinary left me doubting I was reading philosophy at all. Certainly the metaphysics is underexplored, often appearing to take a reductive materialist view, which is ironic in view of Pereira's $(2013,2014)$ widely cited triple-aspect monism. The discussion of the self as a projection includes neither cultural influences nor psychological development and, though mentioned, phenomenological approaches were ignored. Lastly, Pereira is so focussed on the varied particulate foreground of his new theory that he ignores the vast background that unites and gives meaning to these various threads of discourse (which is indicated in my title). However, he is hardly alone in this as most philosophy - indeed, most academic subject areas - also proceed blindly unaware of this "dark energy" ground of the mind.

The basis of Pereira's approach is the old psychological concept of projection, mainly based in Freud, that, as an ego defence mechanism, we project upon others our own psychological weaknesses or failings. This is easy enough to accept as we see examples of this everywhere in daily life (e.g., the cowardly bully or the scapegoater as in racism or sexism). But Pereira seeks a much more pervasive source, making use of Max Velmans' (2009, 2017) concept of projection, which is not psychologically compensatory and is taken to be present in all perception. Reflecting the data of sensory input but not limited by it, the brain projects an appropriate functional image back into the world. Pereira goes a step further and sees projection as resulting in both the interior sense of self and the exterior sense of world. I have problems with this concept because projection implies a projector, and whether this is physical or otherwise is never made clear; further, projection implies that whatever is projected is an object. This means the self 
so projected is an object like the projected world (an idea widely accepted in cognitive science). My questions lead to me to fully agree with Pereira's statement in his conclusion that "the nature of the projective process is still not well defined.” (PEREIRA JR., 2018, p. 226).

My second problem with his approach here is found in the rest of the sentence I quoted above regarding projection: "It may be the result of the integration of distributed conscious processes in the nervous system, or a properly conceptual process based on the cognitive circuits embodied in the mammalian neo-cortex." (PEREIRA JR., 2018, p. 226). In apparent opposition to some of his other consciousness studies papers that imply either a triple aspect (PEREIRA JR., 2013, 2014) or neutral monist (PEREIRA JR. et al., 2018) ontological metaphysics, in this target essay, Pereira seems to lean into reductive physicalism (intended or not). See below.

I further have hesitations at the way the self is defined; there is no mention whatsoever of stages of development, or of culture or the cultural influence of language. Neurophenomenology is mentioned but a phenomenological approach is never fleshed out and this would have helped, for phenomenology provides the most authentic foundation for epistemology. But the main difficulty I have with this erudite essay is found in my title. It is commonly overlooked by psychologists and scientists and by most analytical philosophers; seemingly only the phenomenological philosophers and postSaussurean linguists have understood the overwhelming importance of the contexts of understanding, that is, the implicit, assumed background that makes all human understanding possible. The gestaltists (e.g., KOFFKA, 1922; LEWIN, 1935; WERTHEIMER, 1935) taught us that all perception, perhaps reality itself, is figure and ground (or background), even though the background may not be apparent. In the target paper, details upon details are examined, compared, and contrasted, but nowhere is the curtain pulled back to discuss the everpresent background, implied but not perceived, of consciousness itself. It may be that in knowledge construction, the forest makes the trees (the objects we call trees) possible, just as much as a collection of trees makes a forest.

\section{Projection and physical Reductionism}

As mentioned, a projection implies a projector, which implies that which is projected is an object or intention of that projector. Sometimes in this 
paper, I get the impression that Pereira is suggesting that consciousness itself is a projection, but this is never spelled out as such. Already in his abstract, he states, "The projective process is considered responsible for the generation of the sense of self and the sense of the world, composing an information phenomenal field generated by the nervous system and experienced in the first-person perspective" (PEREIRA JR., 2018, p. 199, italics in the original). Both of these senses, one "interoceptive" and the other "exteroceptive," are experienced by the same (first-person) individual, but even the inner sense of self is not seen as the subject of experience. The sense of his word "sense" implies (at least to me) projections of experience, especially since the self must have objective qualities (learned from others) to be subjectively experienced at all. The objective world is not the fundament of reality, as in reductionist materialism, but is instead the experienced world. It seems experience is being postulated as source of both self and world, which are projected from it: experience-in-itself, perhaps preconscious, could be understood as the information phenomenal field (or, more sensibly, phenomenal information field), which is otherwise further defined in Velmans $(2009,2012)$.

But no, for the rest of the sentence reveals the source of both the selfsense and world-sense and the information phenomenal field is none other than the "nervous system", which is clearly a part of the material human body and non-conscious in itself. If there's a way to take this other than physical reductionism with suggestions of emergence of the non-physical I'd like to know what it is. Pereira later states: "Advances in cognitive, affective and action neurosciences have suggested - on the basis of the activity of the nervous system - that mental activity can occur, in biological species, with different degrees of self-awareness." (PEREIRA JR., 2018, p. 211). This assumes that "different degrees" of activity of nervous system can be directly equated with "different degrees of self-awareness". To my knowledge, nothing like this has ever been proven. One might measure differing levels of activity in the physiological nervous system, but how could one ever measure "different degrees of self-awareness" as opposed to degrees of awareness in itself, much less to assume one causes or at least is equated with the other?

Pereira further notes this rather obvious differentiation: "This structure was philosophically conceived a century ago (HUSSERL, 1913) as consisting of a subjective pole capable of experiencing, and an objective pole composed of the experienced contents" (PEREIRA JR., 2018, p. 199), also putting the emphasis on experience. But this short quotation from Husserl is not pursued, 
which is something of a pity since this paper would benefit greatly, it seems to me, from a more phenomenological approach. Certain phenomenological philosophers like Husserl, Heidegger, and Merleau-Ponty are cited here and there but with isolated words or phrases that are left without a context. For example, a phrase from Merleau-Ponty is twice quoted: "pre-reflexive experience" with which Pereira means to equate "pre-conceptual consciousness". However the assumptions, purpose, and contexts of phenomenology are very different from those of analytical philosophy, so it is difficult to equate any phrases across those contexts. Likewise, neurophenomenology is briefly mentioned, but nothing is really done with the approach. To briefly quote Husserl, Heidegger, Merleau-Ponty or even Wittgenstein out of context as supports in an analytical essay is unfair to their projects. I suggest that a greater emphasis on experience and less reliance on the supposed creative powers of the nervous system would have resulted from actually engaging with the phenomenological perspective or, even better, with more specific neurophenomenological methods (see, e.g., BITBOL, 2008; VARELA, 1996). Neurophenomenology is less scientific and more philosophical, never assuming the primacy of the physical, only looking for correlations.

Pereira certainly has been drawn to physical explanations for cognition and consciousness, especially to do with astrocytes (PEREIRA JR., 2010) and "astroglial hydro-ionic waves" (PEREIRA JR., 2017), but these are more related to cognitive science and neurobiology. Be that as it may, I must close this section by admitting that my acquaintance with other more philosophical papers of Professor Pereira (e.g., 2014) convinces me that my materialist reading his concept of projection is unlikely to sit well with him. Elsewhere (PEREIRA JR. et al., 2018), Pereira the philosopher self-identifies as panprotopsychist, one who accepts that neutral monism (e.g., COLEMAN, 2017a, 2017b) underlies all phenomena, both mental-experiential and physical-material, but is neither in itself: it is neutral (unlike panpsychism, which includes both physical and mental properties). He has offered us a unique ontology that goes beyond double-aspect monism (an unknown single essence manifests in either a mental or a physical aspect) into triple-aspect monism (PEREIRA JR., 2013, 2014), which aspects consist of the mental and physical and the information that links or divides them. The triple-aspect notion has been often referenced and is a contender to explain monistic metaphysics. But in this paper, by my interpretation of the words and assumptions here employed, Pereira seems hardly to be doing philosophy at all - instead settling into an approach that more suggests theoretic cognitive science or neurobiology. 
One of the difficulties of the projection hypothesis is that it must assume a projector and a projected, apparently giving precedence to the former. Furthermore, usual notions of projection imply that projections take place in time and take time; that is, even if there is only a nano-second time-lapse between the projection being "sent" and its appearing elsewhere, it still has taken time and involves cause and effect. This can be problematic when assuming priority or considering objects or systems parsecs apart in the cosmos or that are different in kind or when considering projected psychic phenomena, like minds. Can subjectivity be a projected object? The idea of the holographic projection in which part and whole are intertwined is worth considering here. In the holographic universe, each microcosm "part" mirrors every other part, resulting in mutual instantaneous effect - when one part is changed, the entire hologram changes. (Is this not already suggested by Pereira's use of the term "matrix"?) Indra's Jewelled Net, found in both Buddhism and Hinduism, is an image of this mutuality of unique parts that yet share an identity "nested" within each other. But I would be inclined to go with an even more recent concept from quantum field theory: quantum entanglement, in which seemingly separate and unique parts are yet connected to the point of mirroring or even identity - an acausal link with no time-lapse whatsoever to explain. There is no need to project when the two (or more) elements in question are quantum entangled. (See, e.g., KAUFFMAN, 2014).

\section{PersPeCtives ON THE “HARD PROBlem"}

Though widely known in consciousness studies and often ignored or reviled in the scientific community, the hard problem of consciousness, made famous by philosopher David Chalmers (1995, 1996), cannot be ignored by anyone exploring the "problem of consciousness" without the loss of philosophic credentials. All studies of conscious experience that do not question the metaphysical status of their subject are seen as research into the "easy problems" of consciousness, that is, into questions of how or where in the brain consciousness is produced or what specific activity of the brain or nervous system correlate with which particular conscious experiences. To ignore the hard problem, is to ignore the philosophy of consciousness.

The hard problem of consciousness was recently summed up by Chalmers this way: "The initial problem is the hard problem of consciousness: why and how do physical processes in the brain give rise to conscious experience." 
(CHALMERS, 2018, p. 6). The problem is that there is no conceivable way to demonstrate or reasonably explain how non-conscious objective physiological processes produce non-physiological conscious experience. Whether it be imagined through emergence, supervenience, or natural evolution, the leap from external physiological or biological processes to inner subjective experience finds itself meeting this wall of incomprehension. And this applies to all theories that look to nervous systems or astrocytes or astroglial hydroionic waves as the source of phenomenal consciousness, as well.

The hard problem stated this way assumes the primacy and originating power of the "physical processes in the brain," i.e., reductive materialism. It may be that only with this metaphysical assumption does the hard problem become a problem. It is no problem for philosophical idealism, which assumes mind or awareness or God is the fundamental essence of reality, or even for phenomenology, which begins with the reality of direct experience. For these philosophical approaches, it is the existence of the world or the experience of a world that is the hard problem. Indeed, Bitbol (2008) argues that the approach of neurophenomenology mediates the hard problem, though I retain doubts that any sort of physiological evidence could correlate to all higher conscious experiences.

Chalmers rather prosaically labelled this difficulty the hard problem, but it has been known for a long time under different terminology. Earlier, philosopher Joseph Levine (1983) more descriptively called it the "explanatory gap." Descartes (1641) first and famously attempted to explain the seeming incompatibility of the physical (res extensa) and the mental (res cogitans), but our continued inability to relate them in one coherent worldview was adroitly noted in 1879 by Irish scientist, John Tyndall, referring to the "impossible rift":

The passage from the physics of the brain to the corresponding facts of consciousness is unthinkable. Granted that a definite thought and a definite molecular action in the brain occur simultaneously; we do not possess the intellectual organ, nor apparently any rudiment of the organ, which would enable us to pass, by a process of reasoning, from one to the other. (TYNDALL, 1879).

Scientific approaches generally assume the metaphysical position of reductive or mechanistic materialism in which matter is seen as the primal source. This is a self-defeating way to search for the origins or essence of conscious experience. It must not be forgotten that the assumption of the 
primacy of the non-conscious physical originated in human minds. As I wrote elsewhere: "All objective researches must deal with the epistemological problem that they are themselves products of conscious experience. To objectify a mind-independent reality, then to look for mind in that mindindependent reality, is a bizarre sort of logic to say the least." (NIXON, 1997 , p. 16). All this is meant as a reminder that ignoring the hard problem without turning to idealism, panpsychism, phenomenology, or neurophenomenology may violate the integrity of one's philosophy or cognitive science theory of consciousness.

In all fairness to the author, I think it unlikely that this apparent materialism is his intent. This paper is indebted to the consciousness theories of Velmans (2009, 2012, 2017), who is a physicalist but not a materialist. Velmans recognizes that immaterial energy waves or electromagnetic fields, for example, are still physically real, and that consciousness itself is part of the physical world - which denies reductive or eliminative materialism. It seems likely that Pereira was aiming to suggest that the nervous system be understood as energizing the phenomenal information field of the physical world but not creating it, thus allowing it to be experienced. Pereira in some places embraces this view directly: "Velmans [...] assumes the existence of information processing from a stimulus external to the brain to the central nervous system, where a representation of properties of the stimulus is formed." (PEREIRA JR., 2018, p. 206). Physical yet phenomenal information may always be emerging from the reflexive fluctuations of Velmans' metaphysical reflexive monism, so this may be the ultimate source, leaving the nervous system to act the catalyst.

\section{THE SELF-CONSCIOUS SELF IS NOT NATURAL}

However, in other places, Velmans' phenomenal information field is used to explain the interoceptive projection of the self (as well as the exteroceptive projection of the perceived world), which runs into the same problem of appearing to slip back into objective materialist explanations for subjective phenomena - in this case one's point of view and accompanying self-consciousness (or selfhood itself) - which again ignores the hard problem. Pereira writes: "This field, according to my hypothesis, is constructed by means of a projection of neural activity" (PEREIRA JR., 2018, p. 206, italics in original), which indicates the presumed physiological source of the unique 
point of view of the self. I understand that Pereira means a pre-cognitive feeling state to precede the subjective sense of self when he states:

The subjective pole, or sense of self, is conceived as the "attractor" in the dynamics of sensory, emotional and affective systems of the living body. The attractor state is generated in the feeling history of the individual, and projected as an invariant "identity" in time; the result of this projection is the sense of self. (PEREIRA JR., 2018, p. 208, italics in original).

I like this hint of phenomenal or pre-self-conscious experience, which surely must be the experience of most other animal species and human infants, but it is still extraordinary to suggest that such an interoceptive projection of the nervous system alone created the inner sense of self that we each know and love. It seems this all-powerful nervous system has few other influences, since it is the "ground" of projections: "My proposed approach to the problem is to find the ground of projective operations in the context of neurobiological structures and functions" (PEREIRA JR., 2018, p. 209), Pereira writes.

What this so evidently leaves out, it seems to me, is the proven influence on experienced self-identity of both culture and stages of development. Since both Pereira and Velmans come to some degree from psychology, this strikes me as most unusual. To assume a sense of self appears as the nervous system apparently signals it is time to do so is to put human self agency and each of our unique identities in the hands of the anonymous, unthinking, unfeeling central nervous system.

At least since Vygotsky (1934) and Mead (1934), communal social involvement has been argued to be absolutely central to self-development. Indeed, Mead argued that we learn who we are from the perspective of other people. Lewin (1935) experimentally showed that self and personality were dynamic, changing with social circumstances. Erikson (1959) indicated we go through a series of identity crises from which we either emerge more holistically integrated or psychically wounded. Kegan (1982) presented evidence that self was always evolving through self-creative leaps of insight. Bruner (1990) suggested that the narrative we implicitly tell ourselves was an "act of meaning" that keeps the self-process active. Bandura (1986) with his social-cognitive theory of development is an important transitional figure who found a mediating path between cognitivism and social learning theory. The work of Neisser (1993) cannot be ignored as he demonstrated the ecological and intersubjective sources of the self. 
Aside from being more current, the research and writing of Philippe Rochat (1999, 2001, 2009) has undergone extensive experimental investigation both in the laboratory and the field, unlike many less grounded theories. His work is both empirical yet insightfully interpretive. He works with patterns in phylogenetic evolution and ontogenetic development, especially in early childhood. Rochat boldly rejects the neuroscientific and the evolutionary paradigms as the determining factors in individual conscious development and looks to cultural creativity while moving into the social constructionist camp.

Rochat is radical in his approach, specifically dealing with the evolution and the development (evo-devo) of consciousness, and daring to suggest that, as self-conscious persons, we each arise from our own mutuality. In general, his work has been less concerned with the evolutionary background, but his extensive work with infants has led him to postulate that uniquely human selfconsciousness results from the mutual interaction of the infant's body with objects and ultimately with other people. It is an ecological-phenomenological approach, related to that of Neisser (1993) that sees the early child as both reactive to the world around it and in an important sense independently creative in its responses to it. Self-consciousness is the continuing sense of identity that comes with long-term memory that is, in turn, enabled through the emergence of early speech patterns learned from others. In his recent book most relevant to this critique, Others in mind: social origins of self-consciousness (2009), Rochat considers both the "evo" part of the evodevo pairing while also daring to break scientific habit by taking questions of self and consciousness seriously, both in individual development and in the evolutionary emergence of "modern" behaviours in H. sapiens (especially after the emergence of formal language structures).

As the title indicates, Rochat is addressing the origins of selfconsciousness, not the self as an assumed entity per se. "There is no such thing as a 'core' or an 'individual self'," Rochat declares. "I propose instead that what develops and is unique to human ontogeny is a sense of self that is co-constructed in relation to others." (ROCHAT, 2009, p. 3, italics in original). Being conscious of one's self in relation to others is found only in human development, and Rochat makes this clear from the beginning when he declares: "I start from the simple fact that without others, we would not be. As infants we would not have survived. As adults, we would not have any explicit 
sense of who we are; we would have no ability, nor any inclination to be selfconscious." (ROCHAT, 2009, p. 2, italics in original).

In other words we have an overwhelming desire to be with others, to be recognized by them, and to share in social intimacy. The other side of the coin of desire is fear, and for Rochat, "the fear of social rejection is the mother of all fears." (ROCHAT, 2009, p. 3). One's sense of self becomes deformed under the umbrage of such rejection, and the earlier it takes place, the more powerful its influence. In short, "self-consciousness stands for the representation we hold of ourselves through the eyes of others" (italics in original). Continuing with words that could have come from Mead, "this representation is in essence a social construction, as opposed to an individual elaboration. [...] it originates in relation to others." Rochat's ideas emerge from hard, experimental evidence. In short, Rochat's theories have grounding.

Rochat does not veer off into drawn-out discussions on the nature of consciousness, though he does agree with philosophers like Merleau-Ponty that consciousness, or, better, awareness, exists as embodied experience in a pre-self-conscious manner (or with pre-reflexive experience), what some call phenomenal consciousness. For Rochat (and others) self-consciousness creates the objective self - the self as seen from the imagined perspective of others - that "becomes increasingly external as it refers more and more to the evaluative eyes of others." (ROCHAT, 2009, p. 11). Such an objectification involves higher mental functions that are not in any way determined by the brain, though one may admit they are limited by it. At such levels, each brain functions amongst a network of brains. Rochat writes:

The brain is indeed adapted and shaped to live in a society of minds. If the brain of an individual can be anatomically described as a distinct entity, it can hardly be described as such at most levels of higher functioning, including self-reflection or selfconceptualization. Most of what the brain allows an individual to perform is done in conjunction with other brains, particularly performances such as thinking and talking, even thinking and talking about the self. This basic fact questions the validity of construing the locus of conscious phenomena in the brain of the individual since most of these phenomena depend on conjugate functioning with other brains. (ROCHAT, 2009, p. 10).

This is an explicit statement that marks the move into cultural creativity (aka cultural construction) as a source outside the brain for the brain's 
neural functioning. The focal point and apparent source of all our thinking, reflection, and recognition is the self each of us knows as $I$ or me. Rochat is not the first to emphasize that this self is created as we become conscious of it from the perspective of others, and that this self-consciousness is projected by our pre-reflective, embodied awareness:

[T] he sense and concept of self cannot be conceived independently of the sense and concept of others. They are mutually defining as the two sides of a coin. The basic intuition is that when we think of ourselves, we always and inescapably have others in mind. (ROCHAT, 2009, p. 14, italics in the original).

Rochat has tested his views by comparing multicultural perspectives, including Melanesian children in Vanuatu, and finds evidence amongst the symbolic speech patterns, ritual behaviours, and taboos for the need to be recognized and included and the deep fear of isolation and rejection. Key to such understanding is always found in language and symbol, as in all cultures.

But only the human animal is able to attain such a full symbolic capacity all the time. And this is concomitant upon the ability to become coconscious with other members of the group. This applies in both evolutionary and developmental stages of consciousness. It must remembered that Rochat sees these stages first emerging in the individual at a very young age, and, after crossing from one to the next, the emerging self will often slip back to former stages of consciousness throughout his or her life as each new stage is nested in those that went before.

Rochat's list of levels or stages of "consciousness" follows (and these stages are what make his views so unique and important). I think these are worth comparing with Pereira's "dynamical structure of the flow of consciousness" (PEREIRA JR., 2018, p. 212) and his complex interacting "degrees of selfawareness," "three layers of mental phases," and "levels of consciousness." (PEREIRA JR., 2018, p. 212-217). This is a worthy structure, well thoughtthrough, but going in so many directions I must confess to some confusion. It begins when he states: "'Feeling' here is synonymous to 'experience of qualia'; for instance, to feel the taste of wine is to experience the quale of wine; to feel the smell of a rose is to experience the quale of a rose." (PEREIRA JR., 2018 , p. 213, italics in original). I don't think this is correct. There is no "experience of qualia." That's an unnecessary doubling of categories. Qualia 
are experiences. The quale of wine-tasting is the experience of wine-tasting; there is no distinction (or experience of the experience).

In any case, I offer Rochat's levels as a simplification and perhaps a purification of categories: 1. Non-conscious states of the mind are by definition unknowable but may be equated with lower life forms or dreamless, unaware states of sleep. 2. Unconscious states of mind are understood to be mental contents that have been forgotten or repressed or otherwise ignored. Here he ignores the deeper Jungian theory of a collective unconscious in favor of a more Freudian view. 3. Aware mind states are just that, awareness without differentiation into mental categories or self-reflection. 4. Co-awareness seems to apply to many animals, including warm-blooded mammals; it refers to the simple awareness of the presence of others in the group but without the mindto-mind links provided by symbols. 5. Consciousness, Rochat notes, derives from the Greek suneidesis meaning "communal knowledge" (ROCHAT, 2009 , p. 50), and I must add also from the Latin conscius, meaning "knowing together." It refers to emotional knowing in the individual being. "It exists and vanishes with the body." (ROCHAT, 2009, p. 52). 6. Co-consciousness, however, is the unique human achievement, which should by now be clear in meaning. "I know with others in mind: I become co-conscious." (ROCHAT, 2009 , p. 54, italics in original). It need hardly be said that being co-conscious with other minds in a group is a dynamic process, so it must involve shared avoidances as well as shared intentions.

It must be admitted that these theoretic stages do not emerge directly from Rochat's research and are, in fact, idiosyncratic. From the perspective of consciousness studies, this list is not likely to receive wide acceptance. The most notable contribution is his concept of co-consciousness: the mutuality of minds that occurs after one behaves as a conscious organism, according to Rochat. However, as seen above, the word conscious already implies "knowing together" (from the Latin verb: conscire, "to be mutually aware"), and it may well be that such knowing together precedes the consciousness of self, just as Bruner (1990) indicated. ${ }^{3}$ This suggests co-consciousness might

\footnotetext{
${ }^{3}$ Mead (1934), as often, anticipated this viewpoint. Philosopher Paul Ricoeur later made the strong case for individual subjectivity (self-consciousness) arising from intersubjectivity, a primary identification with others, in Oneself as another (1995). Learning the social codes of language already implies being drawn into otherness (CASSIRER, 1944; KRISTEVA, 1989). Identifying with others before we learn to objectively identify our selves with our embodied experience means such positions as the cognitivist theory of mind and philosophic solipsism become absurd, not to mention suggestions that the nervous system alone projects the sense of self or selfhood itself.
} 
be better understood as, simply, cultural consciousness. To the extent that co-consciousness can be equated with cultural consciousness, its boundaries seem to fluctuate as do the individuals in an identifiable group, but such boundaries certainly exceed individual embodiment. So, though individual phenomenology may "vanish with the body", co-consciousness, i.e., cultural consciousness does not.

This is sufficient coverage of Rochat to serve my purpose. Rochat reveals that no physiological or biological process alone can produce a "sense of self", as Pereira seems to indicate. Cultural intersubjectivity and development are necessary for the self-process, which is learned, not given by nature. It should be clear that Rochat's views on the origin of self-consciousness lie beyond the individual brain in co-consciousness - which I feel is better identified as cultural consciousness - thus in cultural creativity or construction. For such mutuality of identity to emerge, some form of symbolic communication (or interaction), such as language, is necessary as the basis for what might even better be called symbolic communion. In this way, we might be seen as the self-creative species, the species that has achieved cultural consciousness at least some of the time. Other times, admittedly, our self-created cultures find themselves hostile to each other (or within each other) and the biggest threat to human existence becomes other human existents.

\section{THE INVISIBLE BACKGROUND}

Through the core of this essay runs a compelling theme. The idea that experienced reality is a projection from some unknown source is a stirring yet venerable idea. In earlier times, "God" or the gods or some beneficent confluence of supernatural forces was believed to have given rise to all creation. ${ }^{4}$ But today, philosophy of mind recognizes not only the insufficiency of religion but also of both idealism and materialism as sources that project subjective experience, objective experience, and perhaps even the embodied information that unites them. We must turn to some sort of metaphysical monism that is either both mind and matter or is neither mind nor matter, yet manifests as the experienced objective world and the experience of the subjective inner self.

\footnotetext{
${ }^{4}$ Not always beneficent: "For the gnostics, the world itself is evil, the product of an idiot demiurge who suffers from the delusion that he is the real god." (LACHMAN, 2011, p. 89).
} 
In the former dual-aspect category, we have the ancient tradition of panpsychism or panexperientialism (matter-energy experiences its dynamic processing), and we have the reflexive monism of Velmans (2012), which he describes as psychophysical. For the latter (neither mind nor matter), neutral monism - a source that is neither mental nor physical in itself (so no "aspects") - fits the bill. The early versions of neutral monism by philosophers of the late $19^{\text {th }}$ - early $20^{\text {th }}$ included several provisions that are not included in contemporary versions by Coleman (2017a, 2017b) or Pereira et al. (2018). The latter group envisions potential triple-aspects that emerge to produce the structure of world experience, including the possibility for (self-) conscious experience:

We adopt a particular branch of the neutral monist metaphysics [...] which envisages a ground of existence with the potential to originate the three aspects [...], in a process that can be regarded as involving self-organizing elementary energy forms (EEF). This system is called the matrix. Besides material particles originated by quantum processes (transitional), it is also claimed to originate mathematical forms (transitional) that result in information (experiential), and occasions of experience (transitional) that fuse to become conscious qualia and feelings (experiential). (PEREIRA et al., 2018, p.184).

It can be seen that a foundation based in either reflexive monism or neutral monism, with the addition of a theory of projection to explain or interpret the details of the appearance of our lived reality, would be well worth a focussed and deeper exploration. It seems this is what was begun by Pereira in this target paper, and I would have to agree that this is a most worthy intention. However, instead of staying with Velmans and his reflexive monism or with his previous suggestion of a neutral monism that projects in three aspects, the paper undergoes wide zigzags into what seem to me only peripherally related topics, to the point that I often forgot the original point. It is as though Pereira wanted to include every subject he's ever researched instead of keeping his aim true on the very important philosophic topic he originally broached: projection. For this reason, I must repeat that it is no wonder that "the nature of the projective process is still not well defined" (PEREIRA JR., 2018, p. 225), but I do believe Pereira is the type of indefatigable investigator and insightful philosopher who could pursue this topic into the depths or even the heights, if need be. 
Philosophic hair-splitting and getting hung up in peripheral details is endemic to philosophy itself. In fact, I see it as one of the major problems leading to the seeming irrelevance of philosophy to science and the general public and the lack of agreement over possible philosophic progress. Philosophy, like so many other academic areas, is so blinded by the details in the foreground that it is either unable or unwilling to engage the less visible background that must be there to make the foreground figures distinct. The naïve realism that began to infect philosophic thinking in the era that rejected religious concepts but accepted logical positivism and the reductive materialism of science has left many with what might be called cosmophobia, the fear of thinking large or in any terms that suggest metaphysical grandeur. Mysterianism ("it's more than the human mind can know!") is also a culprit here.

Have no fear: I shall not be arguing for metaphysical grandeur in this brief section. That would require much more space. I merely want to make the point - already beautifully made by so many others - that we often blind ourselves to the background reality of the forest as we investigate each individual tree, that is, we study specific exemplars that appear before our senses but ignore the much more widespread background that allows such exemplars to appear as recognizable objects in the first place. Some examples may be in order.

We study the brains of individuals and, sometimes using neurophenomenological methods, we compare the neural imaging patterns that appear in brain scanning methods from various imaging techniques. Neurophenomenology assumes a correlation between phenomenal experiences and neural images but not causation; however, most of the reports in the popular press and science news emphasize that the brain causes such-and-such experience or behaviour. Some scientists have mocked this unquestioning embrace of the materialistic worldview as "neuromania" (e.g. LEGRENZI; UMILTÀ, 2011). Other philosophers of science have noted our experience goes beyond our individual brains so cannot be equated with them. Noës title, Out of our heads: why you are not your brain (2009), makes this explicit. A single brain does not guide one life. Brains exist in concert or competition with other brains. Brains and nervous systems are networks that serve life.

My point is that through learning in our individualistic culture, we come to experience our minds as private and isolated, so it seems to be natural to consider one brain = one mind as a natural equation. However, as already stated above, it seems likely that we forget that each of our individual senses of 
unique selfhood emerged from the within a primary cultural intersubjectivity, likely based in symbolic communication. Each of us is an individual aspect of the larger, changing process of cultural consciousness or co-consciousness, as Rochat (2009) referred to it. Noted linguist Wallace Chafe suggested that our language enabled cultural consciousness metaphorically extended connections between individual brains: "When language is made overt, as in speaking and writing, it is able to provide a link between what would otherwise be independent nervous systems, acting as an imperfect substitute for the synapses that fail to bridge the gap from one mind to another." (CHAFE, 1994, p. 41). This background of semantic assumption in language itself was what William von Humboldt (1836) referred to as the web of language in which everything is connected to everything else in a single web of implied meaning.

In more recent times this recognition that individual words have meaning not as representations of real things in the world but as differentiations of meaning among words themselves has been recognized early in the $20^{\text {th }}$ century by Saussure (1916) who wrote that "nothing is distinct before the appearance of language" and "in language there are only differences without positive terms.” (SAUSSURE, 1959, p. 166). Individual words only have meaning in the context of language itself as an assumed background of understanding. This basic notion that words refer to words and gain meaning by differentiation and deferment is behind much of the phenomenological philosophizing pursued after Saussure by such as Husserl, Heidegger, MerleauPonty, Kristeva, etc. and deconstructionists like Derrida. Others from other fields not inclined to postmodernism such as novelist Walker Percy (1975) and neuroanthropologist Terrence Deacon (1997) have made reference to a symbolic threshold that must be crossed for formal language structures (language in the human sense) to have semantic meaning and the possibility of endless expansion. Linguistic anthropologist Daniel Everett entitles one of his books, Dark matter of the mind: the culturally articulated unconscious (2016), emphasizing the invisible background of meaning. Philosopher Charles Taylor (2016) attempted the definitive statement differentiating the linguistic particularists (words refer to objects) as designative-instrumental and language holists as constitutive expressive. Taylor states that (formal) "language makes possible a new kind of consciousness" (TAYLOR, 2016, p. 6), which leads toward individual self-agency. Cassirer notes: "No longer in a merely physical universe, man lives in a symbolic universe. Language, myth, art, and religion are parts of this universe. They are the varied threads which weave the symbolic net, the tangled web of human experience." (CASSIRER, 1944, p. 
25). Only by crossing the symbolic threshold can we comprehend symbolic meaning: it is not a symbol-to-object one-to-one representation.

What this amounts to is that contrary to our common sense notion of word meaning, meaning is in fact supplied through whole language semiosis. One of the strongest statements of this holism may be found in Merleau-Ponty's (1968) metaphorical ontology of the invisible flesh of the world that connects all things visible. Earlier, Merleau-Ponty (1962) had shown that all perceptions are not only dependent on each other, but also have a reversible aspect so that to touch is also to be touched. Language and the perceptual senses are two primary examples of seemingly separate things or events that are in actuality brought to experience only by being differentiated within a larger context. This larger context is often ignored but is the background of possibility.

Further examples include such things as individual numbers or individual notes of music or individual movements in dance or gestures in communication or moments in time. None of these unique units mean anything on their own. Everything assumes a background. I'd like to suggest this understanding of figure and (back)ground should also apply to consciousness. I can only guess what it's like for other animals or perhaps even plants to be driven entirely by inborn instincts, but it is doubtful that anything whose life depends on social interaction and learning could function in a world without other such conscious beings. The attraction of Whiteheadian panexperientialism and panpsychism is the assumption that these modes begin with particular momentary flashing blips of experience or consciousness that are suggested by our understanding the physical atomic, subatomic, and quantum infinitesimals of the universe. We have no reason for thinking this way; it is an assumption. What is the source that allows these unique "infinitesimals" to have momentary experience? Does experience just disappear from the universe when each experiencing moment passes? If we say that experience or consciousness is already present from the beginning, then it must present in an ongoing manner, always, even if it is not fully active.

This is the basis for such versions of panpsychism such as holistic panpsychism or priority panpsychism or cosmopsychism. Pylkkanen notes with regard to Bohm's undivided universe and the binding problem:

For while the problem typically presupposes in a bottom-up fashion that the properties of the whole have to be explained in terms of the properties of the parts, quantum theory strongly points to a 
monistic ontology, in the sense that the whole is prior to its parts [...] while the ontological interpretation has a panpsychist flavour in postulating that elementary particles have mind-like qualities (when the quantum potential for a particle is non-negligible), its emphasis on the priority of the whole goes against the spirit of the bottom-up way of explaining consciousness characteristic of traditional panpsychism. (PYLKKANEN, forthcoming, 2019).

Though a top-down universal background of awareness suggests a mind, it does not necessarily imply this is the awareness of a self-conscious being, like a deity or even "cosmic consciousness." That this universal awareness is natural but not supernatural should not diminish its "cosmic grandeur." Like so-called quantum gravity or quantum foam, however, such background awareness may not be self-aware or goal-directed in itself, only becoming activated into conscious experience in its more systematic, speciocentric, or individual manifestations. As noted, such background awareness, either quiescent or chaotic, is suggested in physics by theories relating to quantum gravity or the ZPE (zero-point-energy) and an invisible cosmic background by Bohm and Hiley's (1993) implicate order of the undivided universe. If I were to continue, I would now pursue this into philosophies of void consciousness, the clear light, or nothingness (basho) or pure experience (see, e.g., BRUBAKER, 2009; DILWORTH, 1969; NISHIDA, 1911) or even the PCE (pure consciousness event) of Forman (1999). There is too much respectable evidence for such to be reasonably ignored, though common sense western philosophy generally does just that. However, I have gone on this extension too long already. Consciousness studies that do not include the background question of the PCE, that is, awareness-in-itself - without objects or intentionality, has radically truncated its potential for a solution.

\section{Triple-ASPECT COSMOS?}

I close now, but with notice that the suggestion of a universal projection has been made before and on a larger scale. It is inherent in notions of the holographic universe. Talbot (1992), among others, has taken conclusions from Pribham and Bohm to do with the perceptual projections of the holographic or holonomic brain and suggested the entire universe is a holographic projection. The exact nature of the projector is never made quite clear, but the ultimate source seems to be some sort of timeless universal 
mental essence. Leonard (1978), from the human potential movement, earlier referred to the "intention of the universe" and the universal "holonomy: the web of existence." Both of these are a little new agey with questionable extrapolations even for me, but they do indicate where ideas of projections can lead. If such projection is considered possible, perhaps some form of idealism should be given more consideration. However, the universe may be understood as a quiescently aware (void conscious) mind reflexively seeking self-awareness through the creatures it has projected. Pereira quotes Velmans (2009, p. 298) on precisely this large thought: "In so far as we are parts of the universe that, in turn, experience the larger universe, we participate in a reflexive process whereby the universe experiences itself." (PEREIRA JR., 2018, p. 211). The implications of such a suggestion do indeed have metaphysical grandeur.

However, I expect Pereira will not consider such a desertion of ultimate physical matter-energy. And it may not be necessary. Pylakkanen, citing Bohm and Hiley, notes that "the implicate order describes a kind of pre-space out of which the ordinary three dimensional space unfolds." (PYLKKANEN, forthcoming, 2019). Surely this unfolding is similar to a non-intentional projection. The implicate order would be the source that always exists, which is always the ground of our three-dimensional reality. This seems very similar to the position of recent neutral monism and, with the additional thought that our three (or four) dimensional explicate order might in turn affect the implicate order, this even suggests Velmans' reflexive monism.

I'd like to venture that all this cosmic thinking may work as a sort of triple-aspect monism, similar to that put forward by Pereira $(2013,2014)$. Merleau-Ponty's (1968) invisible metaphoric flesh of the world, Bohm and Hiley's (1993) the implicate order, Pereira et al.'s (2018) neutral monism have the common attribute of being unknowable in themselves - they can only be indicated metaphorically or through a sort of via negativa of the known. There is no way to differentiate these metaphysical ultimates beyond their different authors. But what emerges from this unknown source seems to be tripartite projections - each of which is each necessary for the others to exist: the subjective experiential, the objective physical, and the information that unites and distinguishes them. The observed requires observers and vice versa, and both require shared information to make a whole with interacting yet distinctive manifestations. Pereira's triple-aspect theory may describe the projections of reality on a universal scale. 
NIXON, G. M. Projetando as árvores, mas ignorando a floresta: uma breve crítica do target paper de Alfredo Pereira Jr.. Trans/Form/Ação, Marília, v. 41, p. 269-292, 2018. Edição Especial.

Resumo: A teoria da consciência projetiva de Pereira é uma proposta experimental, baseada em diversas fontes, explorando como a consciência pode ser produzida por um mecanismo projetivo que resulta tanto em individualidades privadas ("Eus") quanto em um mundo da experiência. Infelizmente, reunir tantas fontes e métodos sem relaçôes recíprocas significa que nenhum recebe atenção total. Além disso, parece-me que a amplitude desconfortável deste artigo complica desnecessariamente seu projeto; na verdade, pode ocultar o que procura revelar. Se esse conglomerado de diversas fontes e métodos fosse comparado a árvores, o leitor poderia se sentir como o explorador que não pode ver a floresta por causa das árvores. Entáo, novamente, pode ser que o autor esteja tấo preocupado com as figuras de primeiro plano que o pano de fundo sempre presente fique finalmente obscurecido.

Palavras-Chave: Intersubjetividade. Monismo neutro. Projeção. Problema difícil. Construção cultural.

\section{REFERENCES}

BANDURA, A. Social foundations of thought and action: a social cognitive theory. Englewood Cliffs, NJ: Prentice-Hall, 1986.

BITBOL, M. Is consciousness primary? Moving beyond the "hard problem". NeuroQuantology, v. 6, n.1, p. 53-72, 2008.

BOHM, D.; HILEY, B. J. The undivided universe: an ontological interpretation of quantum theory. London: Routledge, 1993.

BRUBAKER, D. "Place of nothingness" and the dimension of visibility: Nishida, Merleau-Ponty, and Huineng. In: PARK, Jin Y.; KOPF, Gereon (Ed.). Merleau-Ponty and Buddhism. Lanham, MD: Lexington Books, 2009. p. 155-179.

BRUNER, J. A. Acts of meaning: four lectures on mind and culture. Cambridge, MA: Harvard University Press, 1990.

CASSIRER, E. An essay on man. New Haven, CT: Yale University Press, 1944.

CHAFE, W. Discourse, consciousness, and time: the flow and displacement of conscious experience in speaking and writing. Chicago: University of Chicago Press, 1994.

CHALMERS, D. J. The puzzle of conscious experience. Scientific American, v. 273, n. 6, p. 80-86, 1995.

The conscious mind: in search of a fundamental theory. New York \& Oxford:

Oxford University Press, 1996.

. The meta-problem of consciousness. Journal of Consciousness Studies, v. 25, n. 9-10, p. 6-61, 2018. 
COLEMAN, S. Panpsychism and neutral monism: how to make up one's mind. In: BRUNTRÜP, G.; JASKOLLA, L. (ed.). Panpsychism: New York: Oxford University Press, 2017a. p. 249-282.

. Neutral monism: A saner solution to the mind/body problem. Philosophy Today. p. 9-11, Aug./Sept. 2017b. Available on: https://philosophynow.org/issues/121/Neutral_ Monism_A_Saner_Solution_to_the_Mind_Body_Problem

DEACON, T. The symbolic species: the co-evolution of language and the brain. New York: W. W. Norton, 1997.

DESCARTES, R. Meditations on first philosophy. Translation by D. Cress. Indianapolis: Hackett, 1993. (First published in French 1641).

DILWORTH, D. A. The initial formations of "pure experience" in Nishida Kitarō and William James. Monumenta Nipponica, v. 24, n. 1-2, p. 93-111, 1969.

ERIKSON, E. Identity and the life-cycle. New York: Norton, 1980. (First published 1959).

EVERETT, D. L. Dark matter of the mind: the culturally articulated unconscious. Chicago: University of Chicago Press, 2016.

FORMAN, R. K. C. Mysticism, mind, consciousness. Albany, NY: Suny, 1999.

HUMBOLDT, W. von. On language: the diversity of human language-structure and its influence on the mental development of mankind. Translation by P. Heath. Cambridge: Cambridge University Press, 1988. (Original in German 1836).

HUSSERL, E. Ideas: general introduction to pure phenomenology. Translation by F. Kersten. Dordrecht: Kluwer Academic, 1913.

KAUFFMAN, S. Beyond the stalemate: conscious mind-body - quantum mechanics free will - possible panpsychism - possible interpretation of quantum enigma. Oct, 2014. Available on: https://arxiv.org/pdf/1410.2127.pdf. Access in: 15 jan, 2019.

KEGAN, R. The evolving self: problem and process in human development. Cambridge, MA: Harvard University Press, 1982.

KOFFKA, K. Perception: an introduction to the gestalt theory. Psychological Bulletin, v. 19, p. 531-585, 1922.

KRISTEVA, J. Language: the unknown - an initiation into linguistics. Translation by A. M. Menke. New York: Columbia University Press, 1989.

LACHMAN, G. The quest for Hermes Trismegistus: from ancient Egypt to the modern world. Edinburgh: Floris Books, 2011.

LEGRENZI, P.; UMILTÀ, C. Neuromania: on the limits of brain science. Oxford: Oxford University Press, 2011. 
LEONARD, G. The silent pulse: a search for the perfect rhythm that exists in each of us. New York: E.P. Dutton, 1978.

LEWIN, K. A dynamic theory of personality. New York: McGraw-Hill, 1935.

MEAD, G. H. Mind, self, and society: from the standpoint of a social behaviorist. Ed. C. Morris. Chicago: University of Chicago Press, 1934.

MERLEAU-PONTY, M. Phenomenology of perception. Translation by C. Smith. London: Routledge and Kegan Paul, 1962.

The visible and the invisible. Translation by A. Lingis. Evanston, IL:

Northwestern University Press, 1968.

NEISSER, U. The perceived self: ecological and interpersonal sources of self-knowledge. Cambridge, UK: Cambridge University Press, 1993.

NISHIDA, K. An inquiry into the good. Translation by M. Abe \& C. Ives. New Haven, CT: Yale University Press, 1990. (Original in Japanese 1911).

NIXON, G. M. A fool's paradise? The subtle assault of the hard sciences of consciousness upon experiential education. Educational Change: A Journal of Role Analysis and Institutional Change, p. 11-28, Spring 1997.

NOË, A. Out of our heads: why you are not your brain, and other lessons from the biology of consciousness. New York: Hill \& Wang, 2009.

PERCY, W. The message in the bottle. New York: Noonday, 1975.

PEREIRA JR, A. Triple-aspect monism: a conceptual framework for the science of human consciousness, In: PEREIRA JR., A.; LEHMANN, D. (ed.). The unity of mind, brain and world: current perspectives on a science of consciousness. Cambridge, UK: Cambridge University Press, 2013, p. 299-337.

. Triple-aspect monism: physiological, mental unconscious and conscious aspects of brain activity. Journal of Integrative Neuroscience, v. 13, n. 2, p. 201-227, 2014.

. The projective theory of consciousness: from neuroscience to philosophical psychology. Trans/Form/Ação, v. 41, n. especial, 2018, p. 199-232.

. Astroglial hydro-ionic waves guided by the extracellular matrix: an exploratory model. Journal of Integrative Neuroscience, v. 16, p. 1-16, 2017.

.; FURLAN, F. A. Astrocytes and human cognition: modeling information integration and modulation of neuronal activity. Progress in Neurobiology, v. 92, p. 405420, 2010.

. et al. Consciousness and cosmos: building an ontological framework. Journal of Consciousness Studies v. 25, n.3-4, p. 181-205, 2018.

PYLKKANEN, P. A quantum cure for panphobia. In: SEAGER, William (Ed.). The Routledge Handbook of Panpsychism. London: Routledge. Forthcoming, 2019. 
RICOEUR, P. Oneself as another. Translation by K. Blamey. Chicago: University of Chicago Press, 1995.

ROCHAT, P. (ed.). Early social cognition: understanding others in the first months of life. Mahweh, NJ: Lawrence Erlbaum, 1999. . The infant's world. Cambridge, MA: Harvard University Press, 2001.

. Others in mind: social origins of self-consciousness. New York: Cambridge University Press, 2009.

SAUSSURE, F. de. Course in general linguistics. Ed. C. Bally; A. Sechehaye. Translation by W. Baskin. New York: Philosophical Library, 1959. (Original in French 1916).

TALBOT, M. The holographic universe. New York: Harper Collins, 1992.

TAYLOR, C. The language animal: the full shape of the human linguistic capacity. Cambridge, MA: Harvard University Press, 2016.

TYNDALL, J. Fragments of science: a series of detached essays: addresses and reviews. London: Longmans, 1879. Available on: http://www.gutenberg.org/files/24527/24527h/24527-h.htm

VARELA, F. Neurophenomenology: a methodological remedy for the hard problem. Journal of Consciousness Studies, v. 3, n. 4, p. 330-349, 1996.

VELMANS, M. Understanding consciousness. 2nd ed. London: Routledge, 2009. . Reflexive monism: psychophysical relations among mind, matter and consciousness. Journal of Consciousness Studies, v. 19, n. 9-10, p. 143-165, 2012.

. What and where are conscious experiences? Dualism, reductionism and reflexive monism. In: ALMQVIST, K.; HAAG, A. (ed.). The return of consciousness: a new science on old questions. Stockholm: Axel \& Margaret Axson Johnson Foundation, 2017. p. 125-143.

VYGOTSKY, L. S. Mind in society: the development of higher psychological processes. Cambridge, MA: Harvard University Press, 1978. (Original in Russian 1934).

WERTHEIMER, M. Gestalt theory. In: ELLIS, W. D. (ed.). A source book of gestalt psychology. London: Routledge \& Kegan Paul, 1935 p. 1-11. (Original in German 1924).

Recebido: $15 / 11 / 2018$

Aceito: $15 / 11 / 2018$ 